\title{
Development of Islamic Microfinance Institutions with Social Capital Mechanism: A Case Study on BMT Tumang, Boyolali
}

\author{
Okta Hadi Nurcahyono ${ }^{1 *}$, and Ghufronudin ${ }^{2}$ \\ ${ }^{1}$ Sebelas Maret University, Indonesia \\ ${ }^{2}$ Sebelas Maret University, Indonesia
}

\begin{abstract}
The increasing public interest in sharia-based (non-ribawi) transaction and finance encourages the growth and development of Tumang Baitul Maal wat Tamwil (BMT) as an alternative sharia-based microfinance institution. This article is the result of research aiming to analyze the role of social capital in the development of Islamic microfinance institutions at the Tumang BMT, Boyolali. This research is a qualitative research with a case study approach. The unit of analysis of this study is that Tumang BMT stakeholders were selected by purposive sampling. The techniques of collecting data used were observation, indepth interviews and documentation. Data validation was carried out using source triangulation, and then data analysis was conducted using an interactive model. The results showed that social capital played a significant role in the growth and development of Tumang BMT's existence in the community. The theoretical analysis used in this paper was Robert Putnam's social capital approach. In his book "Making Democracy Work: Civic Traditions in Modern Italy (1993), Putnam defines social capital as the 'features of social organizations, such as networks, norms, and trust that facilitate coordination and co-operation for mutual benefits. The social capital owned by Tumang BMT includes norms based on Islamic principles that are embedded into members and customers. The members and the community's trust grows through the implementation of principles of corporate good governance (GCG) trust, reflected on the professional service to the community. Reciprocity between BMT and the community could be accomplished through providing financial assistance and sponsorship to various events. Networking (networking) is created through “celengan bumbung' system, Angkat Telepon Moro (ATM), Membangun Keluarga Utama (MKU), organizing football competitions and scholarship programs.
\end{abstract}

\section{Introduction}

The Islamic finance industry in the world continues to experience growth from year to year. In 2016, the total assets of the Islamic finance industry in the world reached US $\$ 2,202$

\footnotetext{
*Corresponding author: okta.hadi@staff.uns.ac.id
} 
billion, an increase from the previous year, which amounted to US \$ 2.063 billion. The achievement of these assets recorded a growth of $6.74 \%$ compared to the previous year, and is projected to increase every year (OJK; 2017). The growth of the Islamic finance industry is projected to continue to increase, this is in line with the increase in the world's Muslim population, the increase in per capita income and wealth owned by Muslim, as well as increasing awareness of Islamic finance.

Islamic microfinance is at the heart of Islamic finance because it addresses one of the fundamental roles of financial intermediaries demanded by Sharia (Mansori, et.al, 2015. Microfinance institutions have an important role to play in reducing poverty in developing countries the majority of people in developing countries are people low and poor income (Karlan \& Goldberg, 2011; Arafah \& Nugrono, 2016). According to the Economist (Mansori, et.al, 2015), the population is one third of the world's poor communities. Over the past few decades, many initiatives have been carried out to reduce poverty in the country. Muslim countries, one of them through Islamic micro-finance institutions, Islamic microfinance is an industry that has developed in several Muslim countries such as Bangladesh, Nigeria and Malaysia, according to the Islamic Finance Development Report 2017, ICD-Thomson Reuters, the country with the largest Islamic financial assets is Iran Following in figure 1 , there are 10 countries with sharia financial assets.

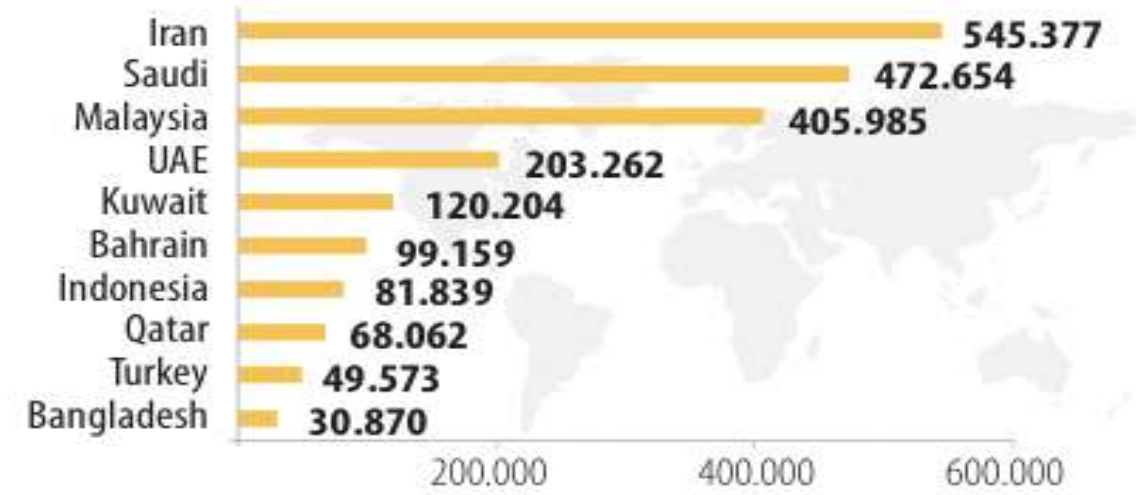

Juta US\$

Fig. 1. Countries with the Largest Islamic Financial Assets

Micro Islamic financial institutions have evolved since 1990. In contrast to conventional banking financial institutions that have succeeded in developing and successfully opening their sharia subsidiaries, Islamic microfinance institutions, such as Sharia BPR, have largely failed to prove themselves as efficient microfinance service providers, and dynamic (Seibel, 2008). This is because Islamic microfinance institutions that are not monitored, such as conventional banks, are a direct threat to their customers such as losing savings. For this reason, the challenge for Islamic microfinance institutions is to gain public trust. One of them is the strategy of social capital, so this article is to answer how the development of Islamic micro financial institutions using social capital strategies.

\section{Methods}

This article is the result of this qualitative research conducted by Tumang BMT, who came from Tumang Village, Cempogo District, Boyolali Regency, Central Java, Indonesia. The approach used in this qualitative research is a case study approach (Yin, 2014). The 
Tumang BMT case was interesting because, in the midst of many failures of sharia-based microfinance institutions in Indonesia, Tumang BMT was able to develop rapidly and become The Best Islamic Micro Finance organized by Karim Bussiness Consulting 2014. The rapid development of Tumang BMT as Islamic microfinance is one of them with a social capital strategy this becomes interesting to study.

The research unit of analysis is the Tumang BMT stakeholders which consist of branch managers, marketing staff, customers and the surrounding community. Meanwhile, the sampling technique is done purposively. Data collection techniques with nonparticipatory observation, in-depth interviews with stakeholders and literature studies. Data validity using source triangulation and data analysis with interactive model analysis (Milles and Huberman, 1984).

\section{Result and Discussion}

Tumang Baitul Maal wat Tamwil (BMT) now renamed into Sharia-based Financing SaveLoan Cooperatives of Tumang BMT has been initiated vigorously by an initiator of transformation, Adib Zuhairi, to release Tumang people from usury trap. Majority Tumang people work in metal craft sector, such as copper and aluminum. Thus, capital infusion is highly desirable. On the other hand, the condition of people is non-bankable and not familiar with banking industry. It is because Tumang people live in Tumang Village, Cempogo Sub District located in the slope of Mount Merapi; thus their access to bank is difficult. Such condition leads the people to rely highly on usurer service for accessing their business capital.

On October 1, 1998, Tumang BMT was established as new sharia-based financial institution in Boyolali region. The existence of Tumang BMT develops rapidly with a total of 20 subsidiaries distributed in both Central Java and DIY, with total members of 22,531 people in 2016, asset of IDR 98 billions in 2015, increasing to IDR 129 billions in 2016. In 2017, this figure increases to 165 billions. In addition, this sharia-based institution has received many awards from Islamic finance award, among others, for The Best Islamic Micro Finance IDR $25<$ Asset < IDR 50 held by Karim Business Consulting on February 2014 (Ricky, 2018).

The existence of Tumang BMT as sharia-based micro financial institution, viewed from sociological perspective can be explained through social capital concept. Putnam in Field (2016: 51) mentions that social capital refers to inter-individual relation, social networking, and reciprocity and reliability norms growing from those relations. From the definition above, it can be concluded that trust, network, norm, and reciprocity is an important aspect in social capital.

\subsection{Trust}

In its early establishment, the attempt of growing public's trust was, of course, not easy. Many attempts taken to introduce the concept of BMT as a new financial institution in the public needs extra power. The management accomplished it through going to the people's houses one by one to visit them and to invite them all at once to join this institution. However, despite good acceptability, people were still reluctant and unwilling to be the members. Eventually, the management thought of how to grow the people's interest and trust in saving.

An innovative measure taken to attract people's sympathy and enthusiasm with saving is to apply bumbung (tubing) diplomatic system. This option was taken by the management because it was inspired with Tumang people's habit of using the perforated bamboo pillar (cagak) as money box. This traditional habit has deeply rooted within the society; thus it 
seemed to attract the people's sympathy to save their money easily. Then, management party produces bumbung massively, each of which was equipped with small padlock and sticker for the members' name and number. Technically, the bumbung was distributed for free to the members with the padlock key brought by Tumang BMT management and then Tumang BMT management would take an amount of fund collected in those bumbungs once a week from one house to another.

From this bumbung diplomatic system, the people's trust arises as characterized with many more people interested in saving their money for such reasons as minimum risk and no fee for renting the bumbung. The effect was so great, from the target of 50 bumbungs in the first week increasing to hundred bumbungs in months thereby having implication to the strengthened capital of BMT. From bumbung, the trust grew and new members come continuously due to words of mouth information. This bumbung method is event used continuously until Tumang BMT develops into the one with tens subsidiaries. Not only through bumbung, trust is grown as well through the utilization of strategic opportunities such as establishing business to provide product and service needed by people. The management then thought of establishing a potential business to provide product and service not existing yet there at that time. The choice was to establishing a business of LPG agent, carbide welding agent, providing sewing tools, pulse counter and initiating and catering on phone network establishment.

The greatness of Tumang BMT is also supported by many programs leading to the improved public trust. Tumang BMT serves not only as a financial institution but also as proselytizing (dakwah) and social institution. In these two functions, Tumang BMT functions as baitulmal or the partner of managing tithe (zakat) from dompet dhuafa and collecting money donation (wakaf) from Badan Wakaf Indonesia (BWI) and then Tumang BMT serves as distributor of zakat, infak, and shodaqoh (alms) to the needy people. Tumang BMT keeps improving its system over times to grow trust and to prevent fraud from occurring through implementing Good Governance Corporate (GCG) with five primary principles: transparency, accountability, responsibility, independency, and equality and fairness in both internal personnel management and professional service to its members. The professionalism of Tumang BMT performance then has implication to the growth of public trust as manifested into the achievement of some awards from many institutions. Consequently, in its almost two-decade existence, Tumang BMT has been rewarded with the achievement of A (Very Good) accreditation by Islamic Microfinance Standard (IMS) of Indonesian BMT Association. Therefore, the work space of KSPPS Tumang BMT has fused into national level since October 2016, after achieving the provincial level previously in 2011. Through these attempts, the members' trust in Tumang BMT is getting stronger.

\subsection{Norm}

Tumang BMT as a sharia-based financial institution plays an important part as role model of sharia value implementation to the public. In running its operational activity, Tumang BMT applies sharia principles to both employees and members as the mutual consensus in achieving the vision of institution. Norm is applied based on Islamic principle inculcated into members and customers, basically, Tumang BMT applies two norm principles: Standard Operating Management (SOM) and Standard Operating Management (SOP). Entire management is required to understand these two principles and to apply them in undertaking its task.

Technical norms include employees' dressing rule according to sharia, behavioral order ad speaking rule with opposite sex, and appeal to give service with smile, greeting, and addressing to customers. Furthermore, the management is required to be disciplined in 
applying the accounting corresponding to the Standard Financial Accounting Statement standardized into computer application program integrated and connected to the internet. Then, the account officer (AO) on duty serving to receive financing installment or saving should be equipped with mobile printer connected to the server in the office. Thus, this norm can grow professional work culture among the employees in giving service to the customers. It leads to the public's stronger trust in Tumang BMT institution.

\subsection{Reciprocity}

Reciprocity is accomplished by Tumang BMT, members, and people through many activities and programs, the benefit of which can be felt collectively. Through Tumang BMT serving not only as the financial institution but also as social institution that distributes zakat, infak, and sedekah to the people, many reciprocal benefits can be felt by both parties. On the one hand, Tumang BMT as an institution benefits from the public's stronger trust in it, and on the other hand, members and people also benefit from the program useful to their social life. The reciprocity between BMT and people can also accomplished through giving financial grant ad sponsorship to many events held by the village, for example, Tumang Fair, sadranan, blood donation, 17-an (Indonesia's Independence Day) competition, and other activities. In addition, the presence of membership building program through routine Qur'an study (pengajian rutin) for samawa family also benefits reciprocally the credibility of Tumang BMT and gives education to the members and people.

\subsection{Social Networking}

The existence of Tumang BMT is highly supported with the presence of social networking. Social networking involves social relation established between Tumang BMT and its members, employees, and external relation. In relation to social networking, Putnam divides social capital into two basic forms: bridging ad bonding social capital. Putnam (2000) in Slamet (2012: 28) revealed that bonding social capital sees more inward and tends to strengthen exclusive identity and homogeneous group. Meanwhile, bridging social capital can result in broader identity and reciprocity. Wolcock added one more social capital form, linking social capital. This social capital form reaches people in different situation, for example those existing out of community completely, thereby encouraging its members to utilize more resources than the ones available in the community (Wolcock in Field, 2016).

Bonding social capital in Tumang BMT has been implemented to many activities, either internally(employees), and externally (customers). Many internal activities like routine Quran study for samawa family is held monthly in turn from an employee's house to another's, recreation activity including picnic, outbound, family gathering, njagong manten (attending wedding party) and takziah (attending mourning ceremony) are internal activities that can strengthen the employees' solidarity and the institutional identity bond. Meanwhile, bonding with customer networking can be manifested into saving system with 'celengan bumbung (tubing money box)', Angkat Telepon Moro (ATM) constituting the cash withdrawal and depositing service using proactive service during work hour, building Excellent Family (MKU) as a means of building, educating, and habituating the good deed (amal saleh) in order to be Excellent family, facilitation program for remote villages, holding badminton event, giving sponsorship to many village events, holding Tumang BMT Cup football competition with national-level player materials and teams, giving grant and help to destitute and orphanage, giving help to disaster victim, distributing Qurban 
meat and providing scholarship to the people, from Elementary to Senior High School Levels.

In addition, Tumang BMT also has economic empowerment program named POKUSMA (Community Business Group) as its bonding social capital. This program aims to alleviate poverty through rotating loose fund loan (qardhul hasan) constituting the loan program without any additional return in its payment given to new members to improve their micro business that has run or to establish new business. Additionally, Tumang BMT management also gives both group and personal facilitation to monitor the progress of individual members' and group's business in order to conduct periodical evaluation.

Linking social capital is established through social relation with other BMT. The initiator, in this case the General Director of Tumang BMT, Adib Zuhairi, establishes linking by synergizing with other BMTs. In 1999, he initiated the establishment of BMT Regional Soloraya Association focusing on synergy and joint training. Soon after, Adib along with his two friends initiated the establishment of Central Java BMT Association. The journey still continued until in 2005 an Association of Indonesia BMT (PBMT) was established. The establishment of PBMT itself is the manifestation of commitment to reinforcing and developing BMT movement. The reinforcement is intended to keep improving many internal indicators in order to optimize the achievement of specified vision and mission. Meanwhile, the development is intended to improve the role and benefit of BMT either qualitatively or quantitatively. PBMT then conducts many sustainable activities and consolidation, one of which is to establish an enterprise to maintain and to strengthen the liquidity of BMT as its members. The enterprises established by PBMT include PBMT Ventura (capitalization), PBMT Institute (Human Resource), PBMT Rowasia (Information Technology), PBMT Ta'awun and PBMT Travel.

Bridging social capital of Tumang BMT is manifested into some cooperation established along with external groups or institutions beyond the relation with other BMTs. This presence of social capital can create a new identity broadly and reciprocity from many parties involved within it. Tumang BMT's activities becoming the part of bridging capital are cooperation, socialization, publication and advocacy intended more to external parties such as Ministry of Cooperatives and SMEs, DPR (Legislative Assembly), DPRD (Local Legislative Assembly, proselytizing institution, badan zakat dan wakaf (an institution managing zakat and wakaf) and of course Islamic organization. Adib, as the director, often sees many national figures, attends many events related to BMT, and hold discussion forum. Such bridging social capital will be good for the external relation to support the need for information that cannot be fulfilled by fellow BMTs. This bridging social capital can serve to create a new identity broadly and reciprocity from many parties involved within it. Such relation enables to establish mutually benefiting connection and network with external association or group. Thus, the progress of Tumang BMT can be achieved more easily because idea exchange keeps developing and stimulating the development of BMT institution and of course the stakeholders within it. 
Table. 1 Development of Tumang BMT with The Social Capital Mechanism

\begin{tabular}{|c|c|}
\hline $\begin{array}{l}\text { The Element of } \\
\text { Social Capital }\end{array}$ & Research Data Finding \\
\hline Trust & $\begin{array}{l}\text { 1. Offering product by door to door } \\
\text { 2. Applying bumbung diplomatic system for members to saving } \\
\text { 3. Open potential services for goods and services (LPG gas agents, carbide welding agents, providers of sewing tools, telephone } \\
\text { services } \\
\text { 4. Optimizing roles as financial institutions and also as da'wah and social institutions }\end{array}$ \\
\hline Norm & $\begin{array}{l}\text { 1. Applying sharia principles to both employees and members as a together consensus in achieving the institution's vision } \\
\text { 2. Implementing two norm principles, namely the Operational Management Standard (SOM) and the Standard Operating } \\
\text { Procedure (SOP) }\end{array}$ \\
\hline Reciprocity & $\begin{array}{l}\text { 1. Optimazing the dual of BMT functions as a financial institution and as a dakwah and social institution makes many reciprocal } \\
\text { benefits felt by customers and members } \\
\text { 2. Providing financial assistance and sponsorship to various events held by the village } \\
\text { 3. The existence of a membership development program through a regular recitation of the samawa family }\end{array}$ \\
\hline Social Networking & $\begin{array}{l}\text { Bonding } \\
\text { 1. Implemented in various activities both internal (employees) and external (customers). } \\
\text { 2. Various internal activities such as a routine study of the regular Samawa family every month which is held in turn from one } \\
\text { house to another employee's house, picnic and outbound, family gatherings, jagong manten and takziah } \\
\text { 3. Whereas bonding with customer networks is manifested in the form of a savings system with a 'Celengan bumbung' model, } \\
\text { Angkat Telepon Moro (ATM), Membangun Keluarga Utama (MKU), assistance program for remote villages, holding } \\
\text { badminton events, giving sponsorship funds to various village events, organizing BMT Tumang Cup soccer match for the } \\
\text { benefit of the poor and orphaned, giving assistance to victims of disasters, distributing qurban meat and providing scholarship }\end{array}$ \\
\hline
\end{tabular}




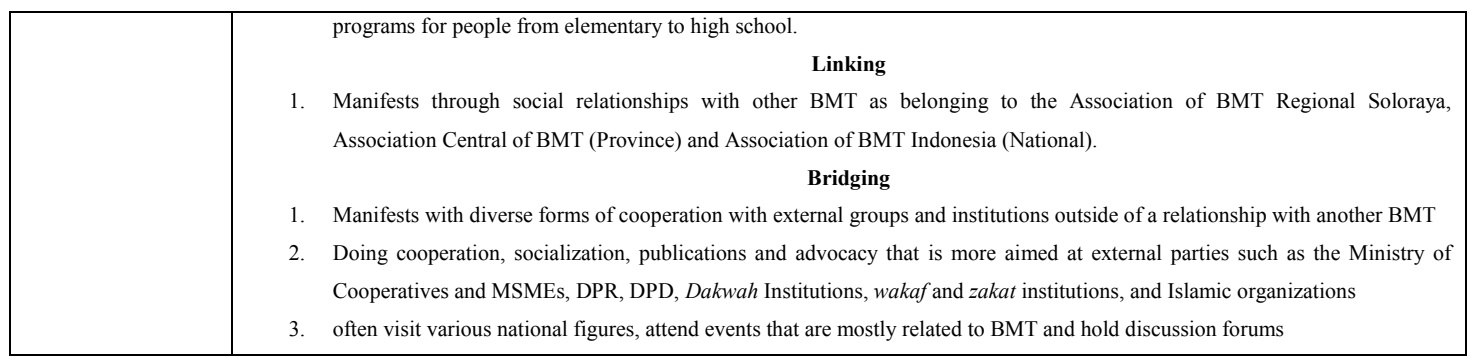




\section{Conclusion}

Baitul Maal wat Tamwil (BMT) Tumang is one of the microfinance institutions that has developed in Indonesia. This year the Tumang BMT has a total of 20 branches both in Central Java and DIY with 22,531 members in 2016, with assets of Rp 98 billion in 2015, and increasing to Rp 129 billion in 2016, on December 2017 the assets reached Rp 165 billion. Various kinds of awards were won by MICRO Sharia financial institutions, one of which was "The Best Islamic Micro Finance IDR $25<$ Asset $<$ IDR 50 held" by Karim Bussiness Consulting. The initial purpose of the existence of the cooperative was to save the Tumang Village people who were in debt by loan sharks. This is because the Tumang community is classified into the structure of rural communities in the slopes of Mount Merapi, so it is not bankable. Besides that, most of them work as metal craftsmen (aluminum and copper), so they need a lot of capital.

The development of Tumang's Baitul Maal wat Tamwil (BMT) is inseparable from the strategy of the social capital it operates. The strategy of social capital according to Robert Putnam in his book "Making Democracy Work: Civic Traditions in Modern Italy (1993), social capital is used as a feature of social organizations, such as networks, norms, and beliefs, which facilitate coordination and cooperation for mutual benefit. As a form of financing that is foreign to the community, Baitul Maal wat Tamwil (BMT) Tumang, builds "trust" in the community by offering products in a doo to door manner. One interesting thing is implementing bumbung diplomacy. This choice was made by management because it was inspired by Tumang community habits who often use bamboo pole or cagak to be used as piggy banks (celengan). As the BMT Islamic micro finance institution Tumang implements "norms or rules" with sharia principles for both employees and members as a joint consensus in both Standard Operating Management (SOM) and Standard Operating Management (SOP). As a micro sharia or Islamic financial institution and as a missionary and social institution (social assistance and sponsorship) make many "mutual relations" benefits arise between Tumang BMT and the community. The "Network" of Tumang BMT with customers is realized in the form of a system of saving money with a model of "celengan bumbung", Raising Moro Phones (ATM), Building a Main Family (MKU), and a village empowerment program.

\section{References}

[1] O. Jasa Keuangan, Laporan Perkembangan Keuangan Syariah 2017 (2017)

[2] S. Mansori, C. S. Kim, and M. Safari, Asian Soc. Sci. 11,273 (2015)

[3] W. Arafah and L. Nugroho, Int. J. Res. Bus. Stud. Manag. 3, 7 (2016)

[4] H.D. Seibel, J. Soc. Issues Southeast Asia. 23, 86 (2008)

[5] R. K. Yin, Studi Kasus Desain \& Metode (Rajawali Pers, Jakarta, 2014)

[6] M. B. Miles and A. M. Huberman, Qualitative Data Analysis, 2nd Ed (sage, 1994)

[7] M. Ricky PD, Inspirasi Bumbung Bambu (Kisah Juang Adib Zuhairi Membangun BMT Tumang) (PT. Aksara Solopos, Surakarta, 2018)

[8] J. Field, Social Capital (USA: Roudledge, Canada, 2008)

[9] R. D. Putnam, R. Leonardi, and R. Y. Nanetti, Making Democracy Work: Civic Traditions in Modern Italy (Princeton university press, 1993)

[10] Y. Slamet, Modal Sosial Dan Kemiskinan: Tinjauan Teoritik Dan Kajian Di Kalangan Penduduk Miskin Di Perkotaan (UNS Press, Surakarta, 2012)

[11] S. Usman, Modal Sosial (Pustaka Pelajar, Yogyakarta, 2018) 